\title{
PERCEPTION OF FORCED DISTANCE LEARNING BY IT STUDENTS: THE INFLUENCE OF GENDER AND JUNGIAN PERSONALITY TYPES
}

\author{
Diana Zagulova \\ Baltic International Academy, Latvia \\ Natalya Prokofjeva \\ Riga Technical University, Latvia \\ Viktorija Ziborova \\ Riga Technical University, Latvia \\ Anastasija Špakova \\ Riga Technical University, Latvia
}

\begin{abstract}
Learning in a pandemic situation has shown an increased role and need for research and implementation of personalized learning, and therefore the factors necessary to take into account when forming such an approach. The purpose of this study was, firstly, to find out how students of technical specialties perceive the fact to refuse from classroom studies, and, secondly, to determine the influence of person's individual characteristics on attitude towards distance learning. The research results showed that a significant part of full-time IT students (about 70\%) reacted positively to the advantages of distance learning and that the attitude towards this form of education is to some extent determined by gender, as well as a manifestation of Introversion-Extraversion and Thinking-Feeling.
\end{abstract}

Keywords: distance learning, Jungian typology, learning styles, Myers-Briggs Type Indicator.

\section{Introduction}

The forced refusal from full-time education and a complete transition to distance learning revealed many problems associated not only with organizational issues, but also with the ambiguous attitude of students to the refusal of full-time studies.

Learning styles vary from person to person, so people with different personality traits tend to prefer different learning styles (Durling, Cross \& Johnson, 1996; Felder \& Silverman, 1988; Zagulova, Boltunova, Katalnikova, Prokofyeva, \& Synytsya, 2019). The peculiarities of the attitude to the forced distance learning form may be due to the psychological characteristics of the personality (Dewar \& Whittington, 2000; Graf, 2007), traits and aspects of the 
learning style (Furnham, Jackson, \& Miller, 1999; Graf, Liu, \& Kinshuk, 2010). In this case, type theories can explain the differences that students have compared to others in different areas. Understanding the characteristics of different types of behavior in the educational process can help in solving problems that students may face (J. C. Carland \& J. W. Carland, 1990).

Currently, when studying the individual characteristics of learning, focus on two main methods: Felder-Silverman Learning Style Model and the Myers-Briggs Type Indicator, MBTI, which is based on The Jungian typology (Shen, Prior, White \& Karamanoglu, 2007).

In the context of this research, the authors believe it is more promising to study the influence of the typological characteristics of the individuals described by C.G. Jung (Jung, 2014) on the attitude to distance learning. Since Jungian typology is based on the mechanisms of selection of signals perceived by the psyche, on the mechanisms of information metabolism, or the rules of the language through which information is transmitted (Augustinavichjute, 1995). The Jungian typology was used to adapt the learning of online writing instructors (Hewett \& Martini, 2018), medics (Ramachandran et al., 2020), learning styles of mathematics of pupils (Kang, 2020), when selecting working groups of engineers (Shen, Prior, White, \& Karamanoglu, 2007) and many others.

Until now, it was possible to analyze the relationship between the features of personal characteristics and distance learning in groups where students themselves chose the type of education that suits them. The uniqueness of this situation lies in the fact that all students, teachers and lectors were deprived of the opportunity to choose and were placed in the conditions of the mandatory use of distance learning. This situation makes it possible to more reliably explore the relationship between different aspects of distance learning and personality traits. Such studies can become the basis for the development of more effective algorithms for creating educational materials from the perspective of personalized learning.

Understanding the influence of the psychotypological personality traits on the attitude to distance learning (DL) will optimize the process of adaptation of students to the absence of full-time studies.

In this regard, the purpose of this article was, firstly, to investigate some aspects of the attitude of students to DL, and, secondly, to determine the influence of typological features on this attitude.

\section{Jungian Typology}

According to P. Guild and S. Garger (Guild \& Garger, 1985), the diversity of types in the context of learning is often recognized in words, but ignored in practice, and the adoption of a variety of styles can help create an atmosphere and 
experience that encourages each person to reach their full potential. According to the views of Isabel Briggs Mayer and Catherine Briggs (Myers, McCaullev, Quenk, \& Hammer, 1998), who developed the theory of Jung's types, a person's orientation is characterized by the Extraversion-Introversion dichotomy, the activity of the mind can be described by two dichotomous functions SensingiNtuition and Thinking-Feeling, and Judgment and Perceiving attitudes (Table 1). At the same time, the Sensing and Thinking functions were classified by Jung as rational (Judgment), and iNtuition and Feeling as irrational (Perceiving). These preferences determine what people pay attention to in different situations, their perception, actions and conclusions (Myers I. B. \& Myers P. B., 2002).

\section{Table 1 Description of Functions according to the Jungian and Myers-Briggs Typology}

(O'Brien, Bernold \& Akroyd, 1998; Hewett \& Martini, 2018; King \& Mason, 2020)

\begin{tabular}{|l|l|l|}
\hline $\begin{array}{l}\text { Orientation } \\
\text { to the } \\
\text { external or } \\
\text { internal } \\
\text { world }\end{array}$ & $\begin{array}{l}\text { Extroversion } \\
\text { (E) }\end{array}$ & $\begin{array}{l}\text { Extroverts are more focused on the external world of people } \\
\text { and things. An extrovert is comfortable among people, he } \\
\text { feels deprivation when there is no interaction with the external } \\
\text { world, is exhausted during solitary activity. }\end{array}$ \\
\cline { 2 - 3 } & $\begin{array}{l}\text { Introversion } \\
\text { (I) }\end{array}$ & $\begin{array}{l}\text { Introverts are mostly focused on the internal world, concepts } \\
\text { and ideas. An introvert needs "personal time” and space to } \\
\text { recharge, he can be “closed” to the external world, has } \\
\text { intrinsic motivation, and prefers individual communication. }\end{array}$ \\
\hline $\begin{array}{l}\text { Preferences } \\
\text { in the field } \\
\text { of } \\
\text { cognitive } \\
\text { perception }\end{array}$ & Sensing (S) & $\begin{array}{l}\text { With the predominance of Sensing (S), people rely more on } \\
\text { sensations when interpreting facts or events, on one or more } \\
\text { of the five senses. These people value experience, perception } \\
\text { is based on reality, focus on details and specifics. They need } \\
\text { practical information and action. }\end{array}$ \\
\cline { 2 - 4 } & iNtuition (N) & $\begin{array}{l}\text { Others rely more on intuition (I), use a more abstract, intuitive } \\
\text { process. They are more focused on concepts, use metaphors, } \\
\text { intuitively perceive information, can give “complete" answers } \\
\text { without explanation. They prefer variety, challenging tasks } \\
\text { and creativity. They can easily get distracted and lose touch } \\
\text { with their environment. }\end{array}$ \\
\hline \multirow{2}{*}{$\begin{array}{l}\text { Thinking } \\
\text { preferences }\end{array}$} & Thinking (T) & $\begin{array}{l}\text { With a pronounced Thinking (T) function, people rely on } \\
\text { logic and consistency when making decisions. As a rule, such } \\
\text { people have a rule-based judgment, they present information } \\
\text { logically, can be analytical and critical, they need a lot of } \\
\text { details. }\end{array}$ \\
\cline { 2 - 4 } & Feeling (F) & $\begin{array}{l}\text { In other cases, they rely more on Feeling (F), decision making } \\
\text { is based on internal or external value systems, more } \\
\text { subjective. Personal, emotional and value judgments } \\
\text { predominate, there may be vivid emotional reactions. These } \\
\text { people can develop better through formal training in an } \\
\text { educational institution. }\end{array}$ \\
\hline
\end{tabular}




\begin{tabular}{|l|l|l|}
\hline $\begin{array}{l}\text { Features of } \\
\text { the way of } \\
\text { making } \\
\text { decisions }\end{array}$ & Judgment (J) & $\begin{array}{l}\text { People in the "Judgment" (J) category prefer to choose a } \\
\text { course and follow it precisely, their lives and actions are more } \\
\text { planned and orderly. They may have a sense of urgency until } \\
\text { a decision is made, they set deadlines and take them seriously. } \\
\text { They prefer to be ahead of deadlines, move consistently from } \\
\text { task to task. }\end{array}$ \\
\cline { 2 - 3 } & $\begin{array}{l}\text { Perception } \\
\text { (P) }\end{array}$ & $\begin{array}{l}\text { Those who belong to Perception (P) prefer to collect all } \\
\text { possible information before acting and remain open to various } \\
\text { options for action. They have flexible deadlines, but they are } \\
\text { time-tolerant and perform better when there is a time frame. } \\
\text { Can plan on the go, prefers multitasking, variety, mixing work } \\
\text { and play. They believe that work should be enjoyable. }\end{array}$ \\
\hline
\end{tabular}

Based on Jung's theory, the Myers-Briggs indicator (Myers, McCaullev, Quenk, \& Hammer, 1998) was developed, which has become a very popular psychometric tool in business and personal development, including education. The frequency of occurrence of individuals with the severity of certain functions differs both in different countries (Table 2) and among different professions (Table 3).

Table 2 Distribution of Dichotomous Population Preferences in the UK, US and Korea (Shen, Prior, White \& Karamanoglu, 2007)

\begin{tabular}{|c|c|c|c|c|c|c|c|r|}
\hline & \multicolumn{2}{|c|}{$\begin{array}{c}\text { Introversion (I) } \\
\text { Extraversion (E) }\end{array}$} & \multicolumn{2}{c|}{$\begin{array}{c}\text { iNntuitive(N) } \\
\text { Sensing (S) }\end{array}$} & \multicolumn{2}{c|}{$\begin{array}{c}\text { Thinking (T) } \\
\text { Feeling (F) }\end{array}$} & \multicolumn{2}{c|}{$\begin{array}{c}\text { Judging (J) } \\
\text { Perceiving (P) }\end{array}$} \\
\hline \multirow{2}{*}{$\begin{array}{c}\text { UK } \\
\mathrm{N}=1634\end{array}$} & $\mathrm{E}$ & 52,6 & $\mathrm{~S}$ & 76,5 & $\mathrm{~T}$ & 45,9 & $\mathrm{~J}$ & 58,3 \\
\cline { 2 - 9 } & $\mathrm{I}$ & 47,4 & $\mathrm{~N}$ & 23,5 & $\mathrm{~F}$ & 54,1 & $\mathrm{P}$ & 41,7 \\
\hline $\mathrm{US}$ & $\mathrm{E}$ & 49,3 & $\mathrm{~S}$ & 73,3 & $\mathrm{~T}$ & 40,2 & $\mathrm{~J}$ & 54,1 \\
\cline { 2 - 9 } $\mathrm{N}=500000$ & $\mathrm{I}$ & 50,7 & $\mathrm{~N}$ & 26,7 & $\mathrm{~F}$ & 59,8 & $\mathrm{P}$ & 45,9 \\
\hline Korea & $\mathrm{E}$ & 41,0 & $\mathrm{~S}$ & 75,0 & $\mathrm{~T}$ & 63,0 & $\mathrm{~J}$ & 63,0 \\
$\mathrm{nyyyyyyyy} \mathrm{N}=13308$ & $\mathrm{I}$ & 59,0 & $\mathrm{~N}$ & 25,0 & $\mathrm{~F}$ & 37,0 & $\mathrm{P}$ & 37,0 \\
\hline
\end{tabular}

Relation of the distribution of different psychotypes in the UK and US are similar, while the inhabitants of Korea differ in a large number of residents with pronounced Introversion, Thinking and Judging.

In the field of research, it is shown the justified use of Jung's personality types both in the educational sphere and in matters of vocational guidance and vocational counseling. Differences in individual priorities of cognitive activity explain the differences in the representation of different types among different fields of activity (Table 3): among Psychology students and Twitter users there are more Perceiving and Feeling, among Managers and Engineering students Thinking and Judging etc. 
SOCIETY. INTEGRATION. EDUCATION

Proceedings of the International Scientific Conference. Volume V, May $28^{\text {th }}-29^{\text {th }}$, 2021. 268-279

Table 3 Typological Results for Accounting Students, Managers and Psychology Students (Briggs, Copeland \& Haynes, 2007; O'Brien, Bernold \& Akroyd, 1998;

Lima \& de Castro, 2019)

\begin{tabular}{|l|c|c|c|c|c|c|c|c|c|c|}
\hline & $\begin{array}{c}\text { Accounting } \\
\text { students } \\
(\%)\end{array}$ & \multicolumn{2}{|c|}{$\begin{array}{c}\text { Managers } \\
(\%)\end{array}$} & \multicolumn{2}{|c|}{$\begin{array}{c}\text { Psychology } \\
\text { students } \\
(\%)\end{array}$} & \multicolumn{2}{|c|}{$\begin{array}{c}\text { Engineering } \\
\text { students (\%) }\end{array}$} & \multicolumn{2}{|c|}{$\begin{array}{c}\text { Twitter users } \\
\text { (\%) }\end{array}$} \\
\hline $\begin{array}{l}\text { Introversion | } \\
\text { Extraversion }\end{array}$ & 50.7 & 49.3 & 49.6 & 50.4 & 51.5 & 48.5 & 41,0 & 59,0 & 64.1 & 35.9 \\
\hline iNntuitive | Sensing & 75.7 & 24.3 & 47.3 & 52.7 & 36.9 & 63.1 & 28,0 & 72,0 & 77,5 & 22,5 \\
\hline Thinking | Feeling & $\mathbf{6 8 . 1}$ & 31.9 & $\mathbf{8 3 . 7}$ & 16.3 & 43.0 & 57.0 & $\mathbf{7 5 . 0}$ & 25,0 & 41,6 & $\mathbf{5 8 , 4}$ \\
\hline Judging | Perceiving & $\mathbf{6 1 . 5}$ & 38.5 & $\mathbf{6 8 . 2}$ & 31.8 & 44.2 & $\mathbf{5 5 . 8}$ & $\mathbf{6 1 , 0}$ & 39,0 & 58,8 & 41,2 \\
\hline
\end{tabular}

\section{Research Methods}

The studies were conducted on the basis of Riga Technical University Faculty of Computer Science and Information Technology in 2020. The course "Algorithmization and Programming of Solutions" is taught to the first year students of Computer Systems (CS), Automation and Computer Engineering (A\&CE), Information Technology (IT), Financial Engineering (FI) and Intelligent Robotic Systems (IRS).

To study the attitude of full-time students to distance learning, they were asked the following questions:

1. Do you agree to completely switch to DL, if at the same time there would be an opportunity for both face-to-face and distance consultations? (answers: yes; rather yes, than no; hard to answer; rather no, than yes; no)

2. Do you agree that DL, in most cases, can fully replace learning in the audience? (answers: Strongly agree; Agree; Partly agree; Disagree; Strongly disagree)

When analyzing the answers to these questions, answers with a positive connotation, such as "Yes", "Rather yes than no", "Strongly agree”, "Agree”, "Partly agree" were combined and labeled as "Yes", respectively combined responses with negative connotation, such as "Rather no than yes", "No", "Disagree," "Strongly disagree" are labeled as "No".

To assess the deficiencies of distance learning, a semantic differential from 0 to 3 was used, where 0 - does not matter; 3 - very important, wherein such factors were assessed: Communication difficulties with teachers, Communication difficulties with fellow students, Lack of student events, Social isolation, Lack of 
competition between students, The need of self-discipline and self-motivation, Fears that the employer will not appreciate the knowledge gained from DL.

To assess the benefits of DL, students were asked to evaluate the importance of such factors as: Money saving, Availability of all course materials, Own choice of learning rhythm, Own choice of learning time, Independence from the studies place, Convenient combination of work and studies, The ability to use audio materials, The ability to use video materials. At the same time, the following answer options were presented: I do not consider it as an advantage, Important, Rather important, Rather not important, Not important.

The MBTI questionnaire was used to determine the psychotype (Myers I. B. \& Myers P. B., 2002).

Frequency data are presented as relative (\%) and absolute numbers (n) of respondents and 95\% confidence intervals (CI) 95\% confidence intervals for frequencies were determined using the Wilson method (Brown, Cai \& DasGupta, 2019). Fisher's exact test (FET) was used to evaluate $2 x 2$ contingency tables. The critical level of significance when testing statistical hypotheses was taken equal to 0,05 . Risks were considered significant if there was no value equal to 1 between the CI.

\section{Research Results}

The attitude of full-time students to distance learning

Faculty of Computer Science and Information Technology students mostly reacted positively to the opportunity to study remotely (Table 4): no more than $30 \%$ of students negatively assessed this form of education. These data significantly differ from the data obtained in other studies, where more than 54\% of students deny this form of learning (Zagulova, Shirjaeva, Gunare, \& Averin, 2020).

Table 4 Assessment of Full Transition to Distance Learning by Full-time Students

\begin{tabular}{|l|c|c|c|}
\hline \multirow{2}{*}{ Question } & \multicolumn{3}{|c|}{ Answer } \\
\cline { 2 - 4 } & $\begin{array}{c}\text { Yes } \\
\mathrm{n}(\%)[\mathrm{CI}]\end{array}$ & $\begin{array}{c}\text { No } \\
\mathrm{n}(\%)[\mathrm{CI}]\end{array}$ & $\mathrm{p}$ \\
\hline $\begin{array}{l}\text { Do you agree to completely switch to DL, if at } \\
\text { the same time there would be an opportunity for } \\
\text { both face-to-face and distance consultations? }\end{array}$ & $\begin{array}{c}127(70,9 \%) \\
{[67,3 \%-74,1 \%]}\end{array}$ & $\begin{array}{c}52(29,1 \%) \\
{[25,9 \%-32,7 \%]}\end{array}$ & 0,0000 \\
\hline $\begin{array}{l}\text { Do you agree that DL, in most cases, can fully } \\
\text { replace learning in the audience? }\end{array}$ & $\begin{array}{c}155(77,9 \%) \\
{[74,7 \%-80,6 \%]}\end{array}$ & $\begin{array}{c}44(22,1 \%) \\
{[19,4 \%-25,3 \%]}\end{array}$ & 0,0000 \\
\hline $\begin{array}{l}\text { Do you agree that the new material is better } \\
\text { perceived in lectures in the audience than in } \\
\text { online broadcasting? }\end{array}$ & $\begin{array}{c}143(71,9 \%) \\
{[68,5 \%-74,8 \%]}\end{array}$ & $\begin{array}{c}56(28,1 \%) \\
{[25,2 \%-31,5 \%]}\end{array}$ & 0,0000 \\
\hline
\end{tabular}


SOCIETY. INTEGRATION. EDUCATION

Proceedings of the International Scientific Conference. Volume V, May $28^{\text {th }}-29^{\text {th }}$, 2021. 268-279

The attitude of full-time students to the negative factors of distance learning

Analysis of students' attitude towards negative DL factors showed that for the majority of students, all factors are important, except one factor "Lack of competition between students". At the same time, more than $30 \%$ of students noted social isolation and the need for self-discipline and self-motivation as a very important factor.

It is worth to mention that the attitude towards two negative distance learning factors was depended on the gender of the students:

- Communication difficulties with teachers during DL, the majority of female students assessed with $2-3$ points $(n=47 / 64,73,44 \%)$, in comparison with male students ( $\mathrm{n}=67 / 131,51,15 \%),(\mathrm{p}=0,003)$;

- Social isolation was considered as a very important factor by $60,00 \%$ of female students $(n=30 / 50)$ and $37,50 \%(n=36 / 96)$ of male students, which is statistically significantly different at the $\mathrm{p}=0,01$ level.

Table 5 Evaluation of Potential Negative Distance Learning Factors by Full-time Students

\begin{tabular}{|c|c|c|c|c|}
\hline \multirow[b]{2}{*}{ Factor } & \multicolumn{4}{|c|}{ Answer } \\
\hline & $\begin{array}{c}0 \\
\mathrm{n}(\%)[\mathrm{CI}]\end{array}$ & $\begin{array}{c}1-2 \\
n(\%)[C I]\end{array}$ & $\begin{array}{c}3 \\
n(\%)[C I]\end{array}$ & $\mathrm{p}_{0-3}$ \\
\hline $\begin{array}{l}\text { Communication difficulties with } \\
\text { teachers }\end{array}$ & $\begin{array}{c}20(10,1 \%) \\
{[8,3 \%-12,6 \%]}\end{array}$ & $\begin{array}{c}139(69,8 \%) \\
{[66,4 \%-72,9 \%]}\end{array}$ & $\begin{array}{c}40(20,1 \%) \\
{[17,6 \%-23,2 \%]}\end{array}$ & 0,006 \\
\hline $\begin{array}{l}\text { Communication difficulties with } \\
\text { fellow students }\end{array}$ & $\begin{array}{c}34(17,1 \%) \\
{[14,7 \%-20,1 \%]}\end{array}$ & $\begin{array}{c}127(63,8 \%) \\
{[60,3 \%-67,1 \%]}\end{array}$ & $\begin{array}{c}38(19,1 \%) \\
{[12,6 \%-17,6 \%]}\end{array}$ & 0,6 \\
\hline Lack of student events & $\begin{array}{c}54(27,1 \%) \\
{[24,2 \%-30,5 \%]}\end{array}$ & $\begin{array}{c}99(49,7 \%) \\
{[46,2 \%-53,3 \%]}\end{array}$ & $\begin{array}{c}46(23,1 \%) \\
{[21,4 \%-27,5 \%]}\end{array}$ & 0,1 \\
\hline Social isolation & $\begin{array}{c}28(14,1 \%) \\
{[12,0 \%-16,9 \%]}\end{array}$ & $\begin{array}{c}105(52,8 \%) \\
{[49,2 \%-56,3 \%]}\end{array}$ & $\begin{array}{c}66(33,2 \%) \\
{[10,0 \%-14,6 \%]}\end{array}$ & 0,0000 \\
\hline $\begin{array}{l}\text { Lack of competition between } \\
\text { students }\end{array}$ & $\begin{array}{c}112(56,3 \%) \\
{[52,7 \%-59,7 \%]}\end{array}$ & $\begin{array}{c}81(40,7 \%) \\
{[37,3 \%-44,3 \%]}\end{array}$ & $\begin{array}{c}6(3,0 \%) \\
{[2,2 \%-4,7 \%]}\end{array}$ & 0,0000 \\
\hline $\begin{array}{l}\text { The need of self-discipline and self- } \\
\text { motivation }\end{array}$ & $\begin{array}{c}31(15,6 \%) \\
{[13,3 \%-18,5 \%]}\end{array}$ & $\begin{array}{c}103(51,8 \%) \\
{[48,2 \%-55,3 \%]}\end{array}$ & $\begin{array}{c}65(32,7 \%) \\
{[11,3 \%-16,1 \%]}\end{array}$ & 0,0001 \\
\hline $\begin{array}{l}\text { Fears that the employer will not } \\
\text { appreciate the knowledge gained } \\
\text { from DL }\end{array}$ & $\begin{array}{c}49(24,6 \%) \\
{[21,8 \%-27,9 \%}\end{array}$ & $\begin{array}{c}111(55,8 \%) \\
{[52,2 \%-59,2 \%]}\end{array}$ & $\begin{array}{c}39(19,6 \%) \\
{[19,2 \%-25,0 \%]}\end{array}$ & 0,2 \\
\hline
\end{tabular}

Note: 0 - does not matter; 3 - very important

The attitude of full-time students to the positive factors of distance learning

The students reacted positively practically to all the factors that were classified as positive. The only two factors Money saving and Convenient combination of work and study were not considered as positive by about $30 \%$ of students, which is most likely due to the insignificance of these factors for them. 
Zagulova et al., 2021. Perception of Forced Distance Learning by it Students: the Influence of Gender and Jungian Personality Types

Table 6 Assessment of Potential Positive Distance Learning Factors by Full-time Students

\begin{tabular}{|c|c|c|c|}
\hline \multirow[b]{2}{*}{ Factor } & \multicolumn{3}{|c|}{ Answer } \\
\hline & $\begin{array}{l}\text { Positive } \\
\text { n (\%) [CI] }\end{array}$ & $\begin{array}{l}\text { Negative } \\
\mathrm{n}(\%)[\mathrm{CI}]\end{array}$ & $\mathrm{p}$ \\
\hline Money saving & $\begin{array}{c}138(69,3 \%) \\
{[65,9 \%-72,4 \%]}\end{array}$ & $\begin{array}{c}61(30,7 \%) \\
{[27,6 \%-34,1 \%]}\end{array}$ & 0,0000 \\
\hline Availability of all course materials & $\begin{array}{c}190(95,5 \%) \\
{[93,5 \%-96,5 \%]}\end{array}$ & $\begin{array}{c}9(4,5 \%) \\
{[3,5 \%-6,5 \%]}\end{array}$ & 0,0000 \\
\hline Own choice of learning rhythm & $\begin{array}{c}175(87,9 \%) \\
{[85,3 \%-89,9 \%]}\end{array}$ & \begin{tabular}{|c|}
$24(12,1 \%)$ \\
{$[10,1 \%-14,7 \%]$}
\end{tabular} & 0,0000 \\
\hline Own choice of learning time & $\begin{array}{c}173(86,9 \%) \\
{[84,2 \%-89,0 \%]}\end{array}$ & \begin{tabular}{|c|}
$26(13,1 \%)$ \\
{$[11,0 \%-15,8 \%]$}
\end{tabular} & 0,0000 \\
\hline Independence from the studies place & $\begin{array}{c}162(81,4 \%) \\
{[78,3 \%-83,9 \%]}\end{array}$ & $\begin{array}{c}37(18,6 \%) \\
{[16,1 \%-21,7 \%]}\end{array}$ & 0,0000 \\
\hline $\begin{array}{l}\text { Convenient combination of work and } \\
\text { studies }\end{array}$ & $\begin{array}{c}135(67,8 \%) \\
{[64,4 \%-71,0 \%]}\end{array}$ & $\begin{array}{c}64(32,2 \%) \\
{[29,0 \%-35,6 \%]}\end{array}$ & 0,0000 \\
\hline The ability to use audio materials & $\begin{array}{c}159(79,9 \%) \\
{[76,8 \%-82,4 \%]}\end{array}$ & $\begin{array}{c}40(20,1 \%) \\
{[17,6 \%-23,2 \%]}\end{array}$ & 0,0000 \\
\hline The ability to use video materials & $\begin{array}{c}183(92,0 \%) \\
{[89,6 \%-93,5 \%]}\end{array}$ & $\begin{array}{c}16(8,0 \%) \\
{[6,5 \%-10,4 \%]} \\
\end{array}$ & 0,0000 \\
\hline
\end{tabular}

Note: Positive - positive connotation of answers; Negative - negative connotation of answers.

The relationship between personality type with the attitude of full-time students to distance learning

The conducted research revealed the distribution of psychotypes among the students of the Faculty of Computer Science and Information Technology (Fig. 1), which is explainable from the professional choice point of view and coinciding with the corresponding literature data presented in Table 3. The only thing is that the number of introverts among our students coincided with Twitter users rather than with Engineering students.

\footnotetext{
\begin{tabular}{l|l|} 
Judging (J) and Perceiving (P) & $\mathrm{J}$ 64,3\% (128) P 35,7\% (71)
\end{tabular}

\begin{tabular}{l|l|l} 
Thinking (T) or Feeling (F) & T 69,3\% (138) F 30,7\% (61)
\end{tabular}

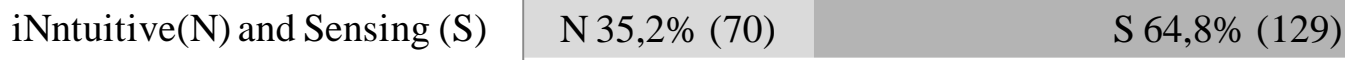

\begin{tabular}{l|l} 
Introversion(I) and Extraversion(E) & I 64,4\% (142) $\quad$ E 35,7\% (57)
\end{tabular}

$0 \% \quad 20 \% \quad 40 \% \quad 60 \% \quad 80 \% \quad 100 \%$

Figure 1 Distribution of Dichotomous Jungian Personality Types according to Scales: Introversion (I) and Extraversion (E), iNntuitive(N) and Sensing (S), Thinking (T) and Feeling (F), Judging (J) and Perceiving (P)
} 
SOCIETY. INTEGRATION. EDUCATION

Proceedings of the International Scientific Conference. Volume V, May $28^{\text {th }}-29^{\text {th }}, 2021.268-279$
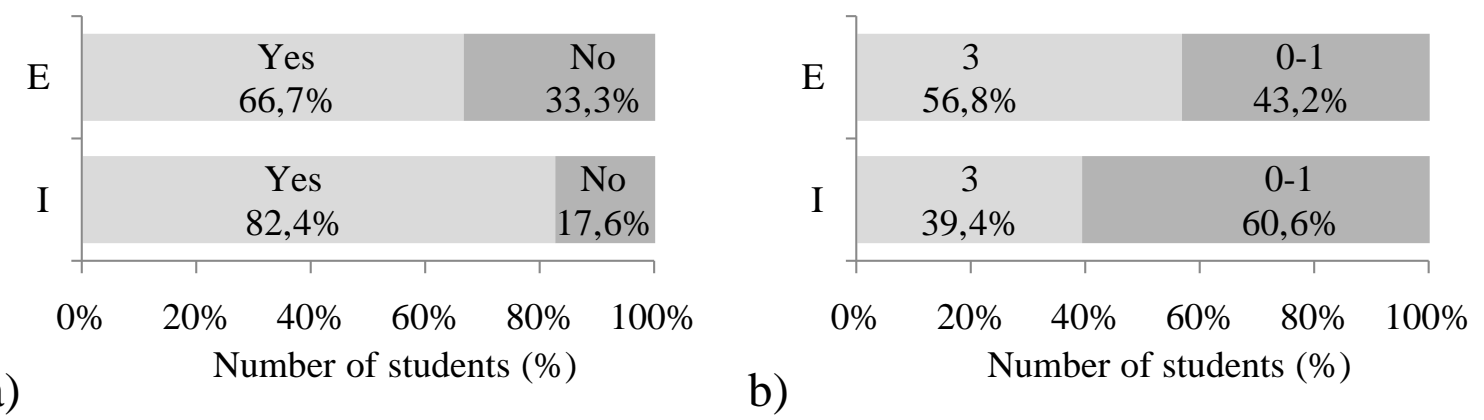

Figure 2 Influence of Introversion (I) and Extraversion (E) on Attitude towards DE: a) the number (\%) I $(n=142)$ and $E(n=57)$ of agreed students (Yes) and disagreed students (No) with the fact that $\mathrm{DE}$ can fully replace full-time education $(p=0,02), b)$ the number (\%) I (n=104) and $E(n=44)$ with different assessment of social isolation importance as a disadvantage ( 0 - does not matter; 3 - very important) $(p=0,04)$. $p$-Values were calculated with Fisher's exact test

The expected attitude towards distance learning was depended on the Introversion-Extraversion index (Fig. 2). The majority of students with pronounced extraversion had a more negative attitude towards DL:

- the risk of negative attitude towards full transition to DL is 1,9 times higher for extraverts than for introverts $\left(\mathrm{CI}_{\mathrm{RR}}=1,14-3,16\right.$ : $\mathrm{CI}$ does not contain value 0 , which means that RR is statistically significant);

- the risk of attributing social isolation during DL to very important problem is 1,4 times higher for extraverts than for introverts $\left(\mathrm{CI}_{\mathrm{RR}}=1,02-2,05\right.$ : $\mathrm{CI}$ does not contain value 0 , which means that $\mathrm{RR}$ is statistically significant).

In addition, the attitude towards distance learning for full-time students was different from students with Feeling and Thinking traits (Table 7):

- $\quad$ the risk of disagreement to full transition to DL is 1,6 times higher for Feeling than for Thinking $\left(\mathrm{CI}_{\mathrm{RR}}=1,03-2,53\right.$ : $\mathrm{CI}$ does not contain value 0 , which means that RR is statistically significant);

- $\quad$ the risk of money saving assessment as an advantage during DL is 1,25 times higher for Feeling than for Thinking $\left(\mathrm{CI}_{\mathrm{RR}}=1,05-1,48\right.$ : $\mathrm{CI}$ does not contain value 0 , which means that RR is statistically significant);

- the risk of assessment of difficulties in communication with teachers as a problem during DL is 1,14 times higher for Feeling than for Thinking $\left(\mathrm{CI}_{\mathrm{RR}}=1,06-2,23\right.$ : $\mathrm{CI}$ does not contain value 0 , which means that $\mathrm{RR}$ is statistically significant);

- the risk of assessment of lacking student events as a problem during DE is 1,25 times higher for Thinking than for Feeling $\left(\mathrm{CI}_{\mathrm{RR}}=1,02-1,52\right.$ : $\mathrm{CI}$ 
Zagulova et al., 2021. Perception of Forced Distance Learning by it Students: the Influence of Gender and Jungian Personality Types

does not contain value 0 , which means that $R R$ is statistically significant);

- $\quad$ the risk of assessment of the self-discipline and self-motivation need as a problem during DL is 1,2 times higher for Feeling than for Thinking $\left(\mathrm{CI}_{\mathrm{RR}}=1,03-1,42\right.$ : $\mathrm{CI}$ does not contain value 0 , which means that $\mathrm{RR}$ is statistically significant).

Table 7 Influence of Thinking (T) Feeling (F) on Attitude towards Distance Learning Factors (p-Values were calculated with Fisher's exact test)

\begin{tabular}{|c|c|c|c|c|}
\hline \multirow{2}{*}{ Question/Factor } & \multirow{2}{*}{ Answer } & \multicolumn{2}{|c|}{ Personality traits } & \multirow{2}{*}{ p-Values } \\
\hline & & $\mathrm{T}, \mathrm{n}(\%)$ & $\mathrm{F}, \mathrm{n}(\%)$ & \\
\hline \multirow{3}{*}{ Consent for full transition to DL } & Yes & $75,6 \%(93)$ & $60,7 \%(34)$ & \multirow{3}{*}{0,0008} \\
\hline & No & $24,4 \%(30)$ & $39,3 \%(22)$ & \\
\hline & Total & $123(100 \%)$ & $56(100 \%)$ & \\
\hline \multirow{3}{*}{$\begin{array}{l}\text { Assessing money savings as } \\
\text { advantages }\end{array}$} & Positive & $64,5 \%(89)$ & $80,3 \%(49)$ & \multirow{3}{*}{0,02} \\
\hline & Negative & $35,5 \%(49)$ & $19,7 \%(12)$ & \\
\hline & Total & $100,0 \%(138)$ & $100,0 \%(61)$ & \\
\hline \multirow{3}{*}{$\begin{array}{l}\text { Assessment of communication } \\
\text { difficulties with teachers as a } \\
\text { problem }\end{array}$} & $1-3$ & $86,2 \%(119)$ & $\mathbf{9 8 , 4} \%(60)$ & \multirow{3}{*}{0,009} \\
\hline & 0 & $13,8 \%(19)$ & $1,6 \%(1)$ & \\
\hline & Total & $100,0 \%(138)$ & $100,0 \%(61)$ & \\
\hline \multirow{3}{*}{$\begin{array}{l}\text { Assessment of lack of student } \\
\text { events as a problem }\end{array}$} & $1-3$ & $\mathbf{8 1 , 9 \% ( 1 1 3 )}$ & $65,6 \%(40)$ & \multirow{3}{*}{0,01} \\
\hline & 0 & $18,1 \%(25)$ & $34,4 \%(21)$ & \\
\hline & Total & $100,0 \%(138)$ & $100,0 \%(61)$ & \\
\hline \multirow{3}{*}{$\begin{array}{l}\text { Assessment of the need for self- } \\
\text { discipline and self-motivation as a } \\
\text { problem }\end{array}$} & $1-3$ & $73,2 \%(71)$ & $\mathbf{8 8 , 6 \%}(39)$ & \multirow{3}{*}{0,03} \\
\hline & 0 & $26,8 \%(26)$ & $11,4 \%(5)$ & \\
\hline & Total & $100,0 \%(97)$ & $100,0 \%(44)$ & \\
\hline
\end{tabular}

Note: 0 - does not matter; 3 - very important

\section{Conclusion}

The results of conducted research did not give expected results by all aspects. Unexpectedly, full-time students have a positive attitude towards distance learning. Apparently, this is due to the specifics of the professional direction and the initial readiness for computer learning without direct contact with the teacher. Most of the Information Technology (IT) sector students study programming and some other exact sciences on their own during their school years.

The purpose of this study was to identify the factors that must be taken into account when personalizing learning and the ability to focus on the psychotype and other characteristics of the student. As studies have shown, female students, more than male students, may need the support of teachers and it is more difficult to experience social isolation. These students should be offered a specific learning 
strategy, giving them the opportunity of consultations, and creating an environment that eliminates social isolation.

Despite the fact that the majority of students have a positive attitude towards DL, there may be a rejection of this form of learning among individuals with high Extraversion and Feeling indexes. More research is needed to understand the reasons for this rejection. However, already at this stage we can say that such students need special preparation for DL. In particular, for students with a pronounced Feeling function, for whom the problem with self-discipline and selfmotivation is more important than for others, it is necessary to create special conditions with external motivation and the structure of the learning process, which does not require independent control of the discipline from the student.

\section{References}

Augustinavichjute, A. (1995). Kommentarij k tipologii Junga i vvedenie v informacionnyj metabolizm. Psihologija i socionika mezhlichnostnyh otnoshenij, 1, 26-33. Retrieved from: http://socionic.info/pdf/aa-p103.pdf

Briggs, S. P., Copeland, S., \& Haynes, D. (2007). Accountants for the 21st century, where are you? A five-year study of accounting students' personality preferences. Critical Perspectives on Accounting, 18(5), 511-537. DOI: https://doi.org/10.1371/journal. pone.0212844.t004

Brown, L. D., Cai, T. T., \& DasGupta, A. (2019). Interval estimation for a binomial proportion. Statistical science, 16(2), 101-133. DOI: https://doi.org/10.1214/ss/1009213286

Carland, J.C., \& Carland, J.W. (1990). Cognitive Styles and the Education of Computer Information Systems Students. Journal of research on computing in education, 23, 114-126.

Dewar, T., \& Whittington, D. (2000). Online learners and their learning strategies. Journal of Educational, Computing Research, 23(4), 385- 403.

Durling, D., Cross, N., \& Johnson, J. (1996). Personality and learning preferences of students in design and design-related disciplines. Loughborough University.

Felder, R., \& Silverman, L. (1988). Learning and Teaching Styles in Engineering Education. Engineering Education, 78(7), 674-684.

Furnham, A., Jackson, C. J., \& Miller, T. (1999). Personality, learning style and work performance. Personality and Individual Differences, 27(6), 1113-1122. DOI: https://doi.org/10.1016/S0191-8869(99)00053-7

Graf, S. (2007). Adaptivity in learning management systems focusing on learning styles. P.H.D's thesis. Institute for Software Technology and Interactive Systems, Faculty of Informatics, Vienna University of Technology.

Graf, S., Liu, T.-C., \& Kinshuk. (2010). Analysis of learners' navigational behaviour and their learning styles in an online course. Journal of Computer Assisted Learning, 26, 116-131. DOI: https://doi.org/10.1111/j.1365-2729.2009.00336.x

Guild, P. B., \& Garger, S. (1985). Marching to different drummers. Alexandria, VA: Association for Supervision and Curriculum Development. Retrieved from: https://files.eric.ed.gov/fulltext/ED269839.pdf 
Zagulova et al., 2021. Perception of Forced Distance Learning by it Students: the Influence of Gender and Jungian Personality Types

Hewett, B. L, \& Martini, R.H. (2018). Educating Online Writing Instructors Using the Jungian Personality Types. Computers and Composition, 47, 34-58.

Jung, C. G. (2014). Psychological types. Routledge.

Kang, Y.S. (2020). High School Students' Mathematics Learning Style and Its Characteristics According to Their MBTI Personality Disposition Types. Communications of Mathematical Education, 34(3), 299-324. DOI: https://doi.org/10.7468/jksmee. 2020.34.3.299

King, S. P., \& Mason, B. A. (2020). Myers Briggs Type Indicator. In B. J. Carducci \& C. S. Nave (Eds.), Wiley encyclopedia of personality and individual differences: Vol. II. Measurement and assessment. Hoboken, NJ: John Wiley \& Sons. Retrieved from: https://online.vitalsource.com/\#/books/9781119793922/epubcfi/6/116\%5B\%3Bvnd.vst.i dref\%3DAc123\%5D!/4/2/2/2/6\%400:0

Lima, A. C. E., \& de Castro, L. N. (2019). TECLA: A temperament and psychological type prediction framework from Twitter data. Plos one, 14(3), e0212844. DOI: https://doi.org/10.1371/journal.pone.0212844

Myers, I. B., McCaullev, M. H., Quenk, N. L., \& Hammer, A. L. (1998). MBTI manual: A guide to the development and use of the Myers-Briggs Type Indicator, 3rd Edition. Palo Alto, CA: Consulting Psychologists Press.

Myers, I. B., \& Myers, P. B. (2002). Gifts differing: Understanding personality type. Palo Alto, CA: Davies-Black Pub.

O'Brien, T.P., Bernold, L.E., \& Akroyd, D. (1998). Myers-Briggs type indicator and academic achievement in engineering education. International Journal of Engineering Education, 14(5), 311-315.

Ramachandran, V., Loya, A., Shah, K. P., Goyal, S., Hansoti, E. A., \& Caruso, A. C. (2020). Myers-briggs Type indicator in medical Education: a narrative review and analysis. Health Professions Education, 6(1), 31-46.

Shen, S. T., Prior, S. D., White, A. S., \& Karamanoglu, M. (2007). Using personality type differences to form engineering design teams. Engineering education, 2(2), 54-66. DOI: https://doi.org/10.11120/ened.2007.02020054

Zagulova, D., Boltunova, V., Katalnikova, S., Prokofyeva, N., \& Synytsya, K. (2019). Personalized E-Learning: Relation Between Felder- Silverman Model and Academic Performance. Applied Computer Systems, 24(1), 25-31. DOI: https://doi.org/10.2478/ acss-2019-0004

Zagulova, D., Shirjaeva, L., Gunare, M. L., \& Averin, A.V. (2020). Personificirovannoe obuchenie: vzaimosvjaz' otnoshenija k distancionnomu obucheniju s psihotipami MBTI. Sovremennye obrazovatel'nye Web-tehnologii $\mathrm{v}$ realizacii lichnostnogo potenciala obuchajushhihsja, 220-225. 